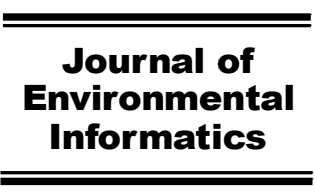

Www.iseis.org/jei

\title{
Variation of Runoff and Sediment Transport in the Huai River - A Case Study
}

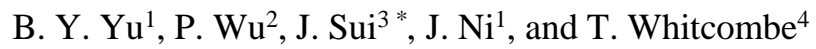 \\ ${ }^{1}$ Anhui and Huai Institute of Hydraulic Research, Bengbu, Anhui, 233000 China. \\ ${ }^{2}$ Department of Environmental Systems Engineering, University of Regina, 3737 Wascana Parkway, Regina, SK, S4S 0A2 Canada \\ ${ }^{3}$ Environmental Engineering Program, University of Northern British Columbia, 3333 University Way, Prince George, BC, V2V $4 Z 9$ Canada \\ ${ }^{4}$ Chemistry, Environmental Science and Engineering Programs, University of Northern British Columbia, 3333 University Way,
} Prince George, BC, V2V $4 Z 9$ Canada

Received October 1, 2013; revised November 10, 2015; accepted December 1, 2015; published online November 16, 2018

\begin{abstract}
Changes in runoff and sediment transport in the Middle Reach of the Huai River have been studied by using 58 years of field data. The runoff yield from the Huai River watershed mainly occurs in the sub-watershed of the river. At the downstream Wujiadu station, the difference in total drainage area between the south and the north branches of the river is $43 \%$ while the difference in runoff yield is only $9 \%$. Sediment yield mainly comes from the headwaters in the northern region with the upstream of the Huai River playing a secondary role. The data demonstrate that there has been little change in long-term average annual runoff in the Middle Reach of the Huai River (MRHR) but there has been a dramatic decrease in average annual sediment transport. This decrease in sediment transport in the Huai River has resulted in changes in the geomorphology of the Middle Reach of the Huai River with time. Further analysis indicates that both the main channel and the floodplain of the estuary of Hongzehu Lake have a tendency towards the deposition of sediment. A trend and regression analysis is used in the compilation of field data, calculations, and analysis.
\end{abstract}

Keywords: runoff, sediment transport, MRHR, riverbed deformation

\section{Introduction}

Erosion involves the detachment and movement of soil particles by both wind and water through natural processes. Naturally occurring erosion can also be accelerated by human activities ranging from the removal of surface vegetation and the activities of the forest industry to rangeland grazing and urbanization $(\mathrm{Xu}, 2003)$. As one of the main sediment sources for aquatic systems, soil erosion can change the sedimentation in river and reservoirs significantly (Shi and Shao, 2000). The impact of sedimentation can be observed at a number of levels. For example, sedimentation in reservoirs can severely affect the operations of hydropower plants and mitigate flood control strategies. Further, sediment transport in rivers is a particularly important indicator in our understanding of the global geochemical cycle and the transport of organic carbon from land to oceans (Wang et al., 2001).

With the growing interest in climate change, numerous researchers have attempted to include the effects of climate change into their assessment of runoff and sediment transport variation in rivers and other aquatic bodies. Some of these reports indicate that sediment transport by rivers has tended to decrease globally in recent years (Walling and Fang, 2003;

* Corresponding author. Tel.: +1-250-960-6399; fax: +1-250-960-5845.

E-mail address: jueyi.sui @unbc.ca (J. Y. Sui).

ISSN: 1726-2135 print/1684-8799 online

(C) 2020 ISEIS All rights reserved. doi:10.3808/jei.202000429
Walling, 2005; Liu et al, 2008; Sui et al., 2008, 2009; Yu et al., 2014). Using an analysis of the date from 142 rivers, Walling (2006) showed that there is not a consistent pattern to the variation in annual runoff. Rather, $8.5 \%$ have shown an increase, $22.5 \%$ a decrease, and $69 \%$ have no statistical change. Similarly, the variations in sediment transport rates were 2.8 , 47.9 and $49.3 \%$, respectively.

By using 25 years data from the Langcang River, Liu and He (2011) evaluated the sediment transport and runoff properties. The evaluation model was based on a regression relationship between sediment and runoff. Yang et al. (2011) also noticed the sedimentation characteristics on the upstream portion of the Yellow River. The temporal variation in 50 years along this reach clearly illustrates a periodic pattern in the sediment and runoff rates. Dong et al. (2008) analyzed the Yangtze River to assess its relationship between runoff and sediment by using data stretching from 1950 to 2005 for the main reach. Zhang et al. (1996) pointed out that the reduction of sediment transport in the downstream reach of the Wei River could be mainly attributed to the decrease of run off from upstream. The literature shows that many researchers have conducted various analyses of runoff and sediment transport for some of the major rivers in China. However, to the best of our knowledge, no analysis has ever focused on the Huai River.

The Huai River watershed is one of the most prosperous regions of eastern China. The river is the main water supply for the 150 million people living within this region. The Huai River also boasts a dramatic and tumultuous history with multiple 


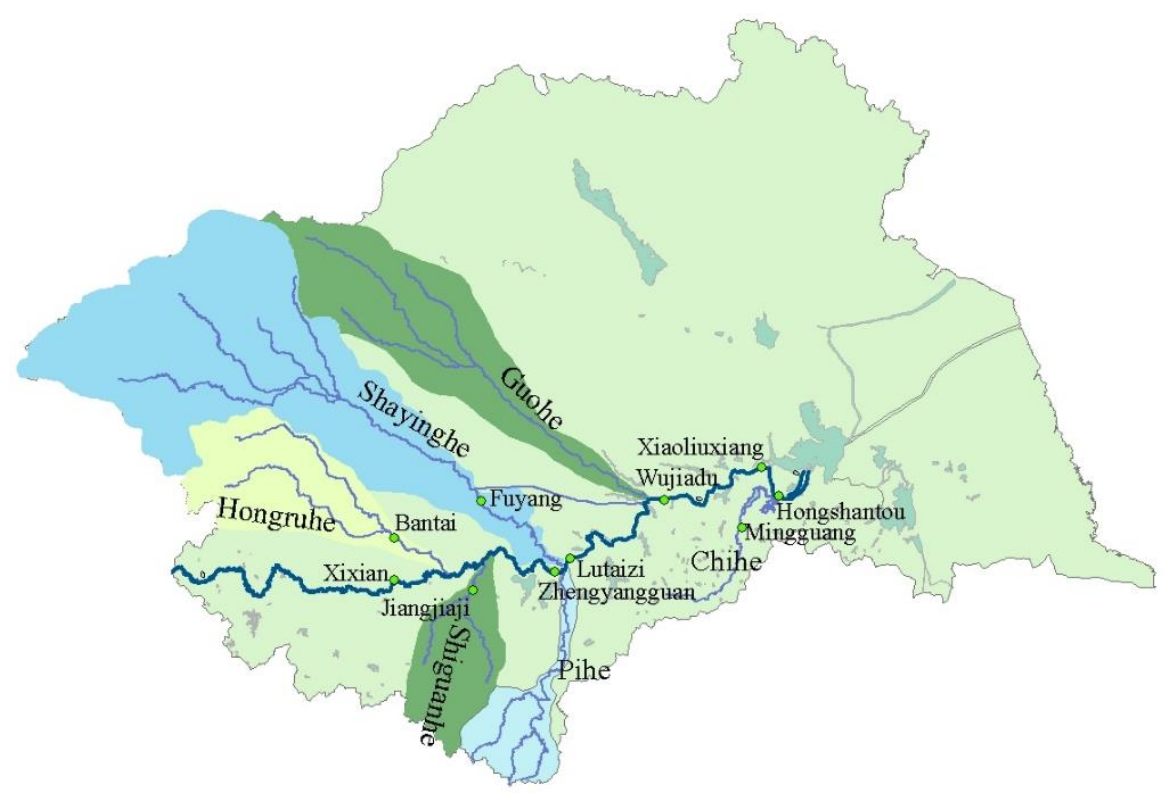

Figure 1. The Huai River and its branches showing the MRHR.

capable of withstanding a high flow rate. Furthermore, over the past few decades the regime of runoff and sediment transport incidents of flooding. Beginning in 1950s, a program to control disastrous flooding was established resulting in more than 195 dams being constructed in the Huai River watershed. In addition, with the development of numerous small factories over the past 30 years, water supply shortages in the Huai River watershed, along with the rest of China, have become a serious problem.

The Huai River watershed is located between the traditional regions of South and North China. The northern tributary of the Huai River has a relatively slow flow velocity while the south tributary is much faster. This is a consequence of many factors, including the differences in the climates and landform. As a result, the sediment transport rate in this river is significantly different from other rivers that have been studied. The Huai River, which originates in the Tongbo Mountain, has a main channel length of approximately $1100 \mathrm{~km}$. It flows roughly from west to east through Henan, Anhui and Jiangsu provinces, and joins the Yangtze River at Sanjiangying. It serves a total drainage area of approximately $1.87 \times 10^{5} \mathrm{~km}^{2}$. The river reach upstream of the Honghekou station belongs to the Upper Reach of the Huaihe River. The river reach from Honghekou station to Zhongdu station (outlet of the Hongzehu Lake) is defined as the Middle Reach of the Huai River (MRHR, as shown in Figure 1).

The present analysis is focused primarily on the MRHR which has a channel length of $490 \mathrm{~km}$ and an average slope of $0.0033 \%$ (HRCC, 2005). Most of the branch rivers and tributaries which join the Huai River system do so along the Middle Reach. For example, the Shihe and Pihe rivers, two major branch rivers, join the Huai River in this region from the south. These two rivers are short and originate within mountainous region with the result that their flow velocity is normally very high. The drainage areas for these branch rivers are between $6000 \mathrm{~km}^{2}$ and $7000 \mathrm{~km}^{2}$. On the other hand, the Shayinghe River is the largest branch river from the north and has a much more extensive drainage area of $3.7 \times 10^{4} \mathrm{~km}^{2}$. It is a much slower moving river servicing a significant population and about one sixth of the Huaihe watershed. Other large branch rivers to the north are the Hongruhe and Guohe rivers. The drainage areas of these two rivers are more than $1 \times 10^{4} \mathrm{~km}^{2}$. The total drainage area of the Huai River at the Zhongdu station is $1.58 \times 10^{5} \mathrm{~km}^{2}$.

The flood retention basins and flood flowing zones in the MRHR play very important roles in flood protection through retention and diversion of high flow. There are 4 flood retention basins and 17 flood flowing zones along the MRHR. The flood flowing zones encompass a total area of $1295 \mathrm{~km}^{2}$ while the 4 flood retention basins have a total area of $1853 \mathrm{~km}^{2}$. The MRHR can be further broken down into specific reaches. The estuary river reach from Hongzehu Lake is $84 \mathrm{~km}$ long with a total area of $318 \mathrm{~km}^{2}$ having been zoned for flood diversion (the Panjiawa flood diversion and the Baojiwei flood diversion). From Hongshantou station to Laozishan station, the river has a relative straight but braided channel with many islands and point bars. The main channel is shallow with an average width of this estuary river reach being $730 \mathrm{~m}$. During flooding periods, the water surface can be as much as 5 or $6 \mathrm{~km}$ in width (HRCC, 2005).

This Middle Reach of the Huai River plays a very important role in the floods control due to a combination of climatic conditions in the region, the flat landscape for much of this portion of the watershed, and the lack of storage capacity of the Huai River has been significantly altered due to interventions intended to prevent soil erosion in the watershed. A better understanding of the changes in sediment transport within the river system and deformation of riverbed along this river reach 
is necessary to better engineer flood control and mitigate damage to the surrounding land and population.

As a consequence of the economic and social importance of this stretch of the Huaihe River system, the MRHR is the main focus of our analysis. By using field data obtained from River Sediment Bulletin of China for the last 58 years (MWR, 2002 2006), a case study has been conducted to assess the variation of runoff and sediment yield during this period.

\section{Methodology}

Three analytical approaches have been employed to compare the annual variation of sediment and runoff: Exponential Smoothing (ES), Cluster Analysis (CA) and Regression Analysis (RA).

\subsection{Exponential Smoothing}

Exponential smoothing is a technique that can be applied to time series data to produce a smoothed data set suitable for making forecasts. The time series data themselves are a sequence of observations.

For example, given a data series: $X_{1}, X_{2}, \ldots, X_{n}$, application of Exponential Smoothing can provide a value for $X_{n+1}$ :

$\hat{X}_{n+1}=\frac{X_{n}+w X_{n-1}+w^{2} X_{n-2}+\cdots \cdots+w^{n-1} X}{1+w+w^{2}+\cdots \cdots+w^{n-1}}$

for which $0<w<1$. If a value is assigned such that $1-w=\alpha$, where $\alpha$ is the coefficient for ES, then a smaller value of $\alpha$ will create a smoother line from the data set. In the present study, a value of $\alpha=0.2$ was utilized.

\subsection{Cluster Analysis}

Cluster analysis or clustering is the task of grouping a set of objects in a way that objects in the same group or cluster are more similar to each other than to those in other groups. To date, the most commonly used cluster analysis was developed by Fisher (1958) and is called an Optimal Partitioning Method. It is also sometimes referred to as the Fisher method. In the present study, the runoff data for 58 years of observations can be treated as one group with a chronological order. By using the Fisher method to organize this group, runoff data with similar characteristics can be set in one subgroup. Flow variation can then be ascertained using the following methodology.

A sample is divided into $k$ smaller samples and $P\left(n, k / i_{1}\right.$, $i_{2}, \ldots, i_{k}$ ) can be used to show the $k$ divide for $X_{1}, X_{2}, \ldots, X_{n}$. If the hypothesis that value of $D(i, j)$ is used to represent the diameter of Sum of Squares of Deviations where:

$$
D(i, j)=\sum_{i=i}^{j}\left(x_{i}-\bar{x}_{i j}\right)^{T}\left(x_{i}-\bar{x}_{i j}\right)
$$

then the target function can be expressed as $e[P(n, k)]$. The optimal partitioning method is to then look for $P(n, k)$ such that
$D(i, j)$ has the smallest value or:

$e[P(n, k)]=\min \left(\sum D(i, j)\right)$

Finding the best $k$ value involves analyzing the relationship between $e[P(n, k)]$ and $k$. For the data sets in the present study, it was found that once $k$ is greater than 3 , the value of $e[P(n, k)]$ results in the smallest value for $D(i, j)$. Hence, we used $k=3$ in the present study.

\subsection{Regression Analysis}

Regression analysis is a statistical approach for estimating the relationships within data sets particularly when determining the relationship between one independent variable (time) and one or more dependent variables (flow; sedimentation). In this study, regression analysis was mainly used to calculate the variation of sediment upstream from the Lutaizi station which then allowed the impact of sediment from upstream to be analyzed.

\section{Results and Analysis}

\subsection{Changes in Runoff in the MRHR}

The drainage area of the Huai River at the Wujiadu station is $1.21 \times 10^{5} \mathrm{~km}^{2}$ and $1.24 \times 10^{5} \mathrm{~km}^{2}$ at the Xiaoliugang station, which is the last control gauging station on the MRHR. The Chihe River is a branch river to the estuary river reach of the MRHR. The Mingguang gauging station is the last station on the Chihe branch river before it enters into the Huai River. The drainage area of the Chihe River at the Mingguang station is $3470 \mathrm{~km}^{2}$. Based on observations from 1975 to 2005 at the Wujiadu station, it is found that the long-term average annual runoff for the Huai river is $2.61 \times 10^{10} \mathrm{~m}^{3}$.

The major branch rivers to the Huai River in the northern region are the Hongruhe River, Shayinghe River and Guohe River (Figure 1; Table 1). The total drainage area of these three branch rivers accounts for $51 \%$ of the total drainage area of the Huai River watershed at the Wujiadu station. The total runoff generated from these three sub-watersheds, however, only accounts for $29 \%$ of the total runoff of the Huai River at the Wujiadu station. The major branch rivers to the south of the Huai River are the Shihe and Pihe rivers, which account for a much smaller portion, at $8 \%$, of the drainage area of the Huai River at the Wujiadu station. The total runoff generated from these two sub-watersheds, however, accounts for $20 \%$ of the total runoff of the Huai River at the Wujiadu station. The total drainage area of three major branch rivers in the northern region of the Huai River is $43 \%$ more than that of two major branch rivers in the southern region of the Huai River but the total runoff generated from the northern branch rivers is only $9 \%$ more.

Table 2 shows the discharge observed at the Xiaoliugang and Mingguang gauging stations. From this table, it can be observed that the average annual flow rate for the Chihe River at Mingguang gauging station is approximately $2.3 \%$ of the 


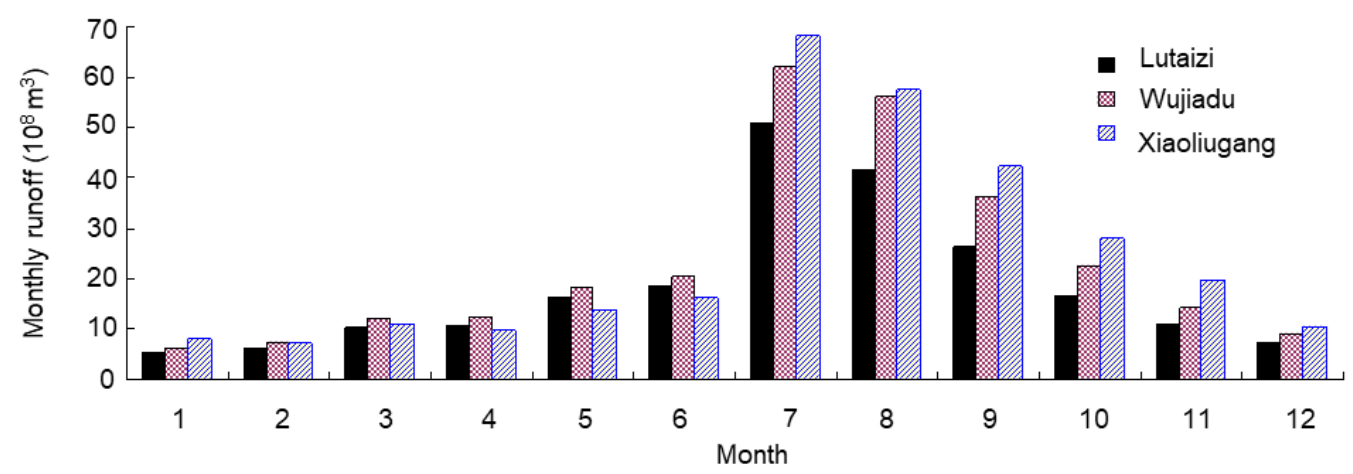

Figure 2. Average monthly runoff at the Lutaizi, Wujiadu and Xiaoliugang stations.

Table 1. Contribution of Runoff to at the Wujiadu Station on the Huai River

\begin{tabular}{|c|c|c|c|c|}
\hline \multicolumn{5}{|c|}{ Percentage out of that at Wujiadu station (\%) } \\
\hline & Wujiadu station & $\begin{array}{l}\text { Major branch rivers in the northern } \\
\text { region of the Huai River }\end{array}$ & $\begin{array}{l}\text { Major branch rivers in the } \\
\text { southern region of the Huai River }\end{array}$ & $\begin{array}{l}\text { Xixian } \\
\text { station }\end{array}$ \\
\hline Drainage area & $1.21 \times 10^{5} \mathrm{~km}^{2}$ & $51 \%$ & $8 \%$ & $8 \%$ \\
\hline Total runoff & $2.61 \times 10^{10} \mathrm{~m}^{3}$ & $29 \%$ & $20 \%$ & $15 \%$ \\
\hline
\end{tabular}

Table 2. Flow of the Huai and Chihe Rivers

\begin{tabular}{|c|c|c|c|c|c|c|c|c|}
\hline \multirow{2}{*}{ River } & \multirow{2}{*}{ Station } & \multirow{2}{*}{ Period } & \multicolumn{2}{|l|}{ Average annual } & \multicolumn{4}{|c|}{ Volume of flow $\left(10^{8} \mathrm{~m}^{3}\right)$} \\
\hline & & & Discharge $\left(\mathrm{m}^{3} / \mathrm{s}\right)$ & Volume $\left(10^{8} \mathrm{~m}^{3}\right)$ & Max. & Year & Min. & Year \\
\hline Huai & Xiaoliugang & $\begin{array}{l}1983 \sim 1988 \\
1994 \sim 2007\end{array}$ & 905.40 & 285.73 & 668.38 & 2003 & 54.95 & 2001 \\
\hline Chihe & Mingguang & $1958 \sim 2005$ & 21.03 & 6.64 & 29.20 & 1991 & 0.07 & 2004 \\
\hline
\end{tabular}

Table 3. Contribution of Sediment to the Wujiadu Station on the Huai River

\begin{tabular}{|c|c|c|c|c|}
\hline & Wujiadu station & $\begin{array}{l}\text { Major branch rivers in the } \\
\text { northern region of the Huai } \\
\text { River }\end{array}$ & $\begin{array}{l}\text { Major branch rivers in the } \\
\text { southern region of the Huai } \\
\text { River }\end{array}$ & Xixian station \\
\hline Annual sediment transport & $6.07 \times 10^{6} \mathrm{t}$ & $4.18 \times 10^{6} \mathrm{t}$ & $5.90 \times 10^{5} \mathrm{t}$ & $1.89 \times 10^{6} \mathrm{t}$ \\
\hline \multicolumn{2}{|c|}{ Percentage out of that at Wujiadu station (\%) } & $69 \%$ & $10 \%$ & $31 \%$ \\
\hline
\end{tabular}

Table 4. Sediment Transport of the Huai and Chihe Rivers

\begin{tabular}{|c|c|c|c|c|c|c|c|c|}
\hline \multirow[t]{2}{*}{ River } & \multirow[t]{2}{*}{ Station } & \multirow[t]{2}{*}{ Period } & \multicolumn{2}{|l|}{ Average annual } & \multicolumn{4}{|c|}{ Mass of sediment $\left(10^{7} \mathrm{~kg}\right)$} \\
\hline & & & Sediment concentration $\left(\mathrm{kg} / \mathrm{m}^{3}\right)$ & Total $\left(10^{7} \mathrm{~kg}\right)$ & Max. & Year & Min. & Year \\
\hline Huai & Xiaoliugang & $\begin{array}{l}1983 \sim 1988 \\
1994 \sim 2007\end{array}$ & 0.21 & 605.36 & 1575.27 & 1984 & 15.42 & 2001 \\
\hline Chihe & Mingguang & $1958 \sim 2005$ & 0.52 & 34.62 & 215.93 & 1991 & 0.02 & 2004 \\
\hline
\end{tabular}

average annual discharge for the Huai River at Xiaoliugang gauging station. Furthermore, the Chihe River enters into the Nushan Lake and the Qili Lake after Mingguang station before joining the Huai River.

The river reach of the Huai River from the Wangjiaba station to the Lutaizi station is $140 \mathrm{~km}$ while the difference in drainage area between these two stations is $5.8 \times 10^{4} \mathrm{~km}^{2}$ and accounts for $47.8 \%$ of the drainage area of the Huai River at the Wujiadu station. The runoff for the Huai River increases by $1.15 \times 10^{10} \mathrm{~m}^{3}$ in this reach which accounts for $44 \%$ of the total runoff of the Huai River at the Wujiadu station. Results show that the runoff yielded from the Huai River watershed mainly occurs in the sub-watershed of the Upper Reach of the Huai River at the Zhengyangguan station.

Figure 2 shows the long-term average monthly runoff at the Lutaizi, Wujiadu and Xiaoliugang stations on the Huai River. The average monthly runoff differs significantly from month to month. The highest monthly runoff occurs in July while the lowest monthly runoff occurs either in January or December. The figure illustrates the disparity between maximum and minimum runoff and highlights the seasonal structure to the flow rate. The flood season (typically from June to September) accounts for $56 \sim 70 \%$ of the annual total runoff. Further, the ratio of maximum annual runoff to minimum 
annual runoff is more than 13 while the variation coefficient of annual runoff varies from 0.55 to 0.86 . It is also found that the coefficient increases from the south to north regions of the Huai River with the coefficient in the sub-watershed of the plateau region being much more than in the mountainous region.

\subsection{Changes in Total Sedimentation in the MRHR}

Over the course of history, the sediment concentration of the Huai River has changed significantly but at present, it is relatively low in comparison to other major rivers in China, such as the Yellow River. However, there is a correlation between discharge and sediment concentration as demonstrated in Figure 3. Based on measurement data from 1975 to 2005 at the Xixian (upstream), Wujiadu and Xiaoliugang stations on the Huai River, together with sediment transport data in the major branch rivers of the Huai River, it can be determined that the average annual sediment transport of Huai River at the Wujiadu station is $6.07 \times 10^{6} \mathrm{t}$. As indicated in Table 3, the sediment transport at the upstream Xixian station on the Huai River accounts for $31 \%$ of sediment transport at the downstream Wujiadu station. Sediment transport yielded from the major branch rivers in the northern region of the Huai River (the Hongruhe River, Shayinghe River, and Guohe River) accounts for $69 \%$ of sediment transport at the Wujiadu station. Sediment transport yielded from the major branch river in the southern region of the Huai River (the Shihe River) accounts for $10 \%$ of sediment transport at the Wujiadu station. Characteristics of sediment yield in the northern region are completely different from those in the southern region of the Huai River. Sediment yield of the Huai River from the sub-watershed of MRHR mainly originates from the branch rivers in the northern region of the Huai River.

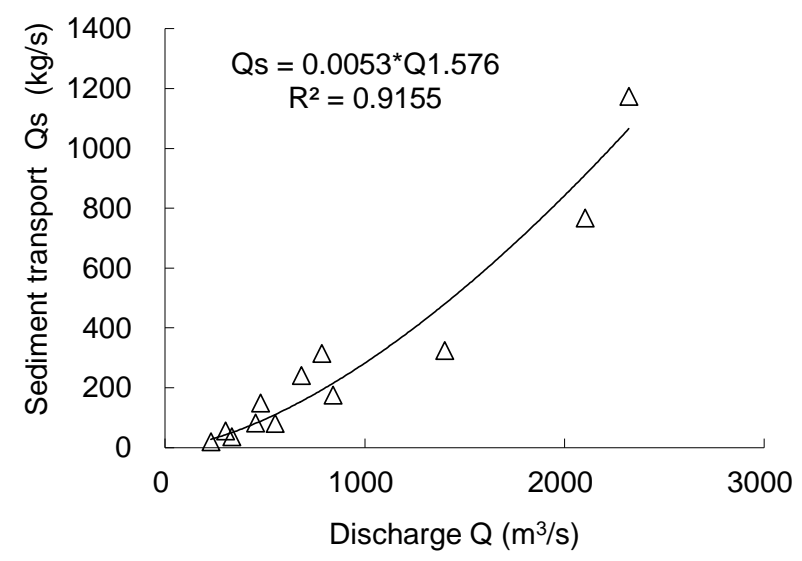

Figure 3. Relationship between sediment transport and flow discharge at the Wujiadu stations.

Furthermore, the contribution of sediment from branch rivers to the MRHR decreases along the lower section of the MRHR (namely, the estuary river reach of the MRHR to the Hongzehu Lake). Tables 3 and 4 show that based on the data from Mingguang station on the Chihe river, the average annual flow rate accounts for only $2 \%$ of that at the Xiaoliugang station on the Huai River. The average annual sediment transport at the Mingguang station accounts for only $6 \%$ of that at the Xiaoliugang station. The Chihe River flows through Nushan Lake and Qili Lake before joining the Huai River downstream of the Mingguang station. Consequently, the sediment concentration of the Chihe River decreases significantly before joining the Huai River due to low flow velocity in Nushan Lake and Qili Lake and the contribution of sediment from the Chihe branch river to the estuary river reach of the Huai River is very low. Therefore it can be concluded that nearly all sediment transported in the estuary river reach is from the upstream section of the Huai River at the Xiaoliugang station.

Figure 4 shows that the average monthly sediment transport at the Lutaizi, Wujiadu and Xiaoliugang stations on the Huai River. In a pattern similar to the monthly runoff (Figure 2), the average monthly sediment transport differs significantly from month to month in an annual cycle. The highest monthly sediment transport occurs in July while the lowest monthly sediment transport occurs in either January or December. At the Wujiadu station, the ratio of the maximum monthly sediment transport in July to January is 156. During the flooding season from June to September, sediment transport accounts for 73 to $84 \%$ of the annual total; while at the same time, runoff only accounts for 56 to $70 \%$ of the annual total. The variation coefficient of annual sediment load is 0.78 . Further, along the estuary river reach of the MRHR to the Hongzehu Lake, sediment transport changes significantly from month to month. During flooding season from June to September, the flow discharge of the estuary river reach of the MRHR accounts for $63 \%$ of the annual total; while sediment transport accounts for $82 \%$ of the annual total.

Tables 5 and 6 are used to show the monthly runoff and sediment transport in the three stations as shown in Figure 2 and Figure 4.

\subsection{Trend Analysis of Runoff}

Extreme-value analysis is a probability analysis of the largest or smallest values in a data set. Each of the extreme values is selected from an equal time interval. The samples are verified to be homogenous before conducting any statistical studies. Inhomogeneity is often recognized through trends a significant dependence on time. Trend analysis for discharge and sediment transport of the Huai River has been carried out based on measurement data collected from 1950 to 2007 at the Wujiadu station.

Using the existing data sets, a number of assessments have been conducted to determine statistical averages of runoff for different periods. Exponential smoothness analysis and clustering analysis have been carried out to study the features of runoff in the MRHR. The average annual runoff of the Huai River at the Wujiadu station from 1950 to 2007 has been determined to be $2.77 \times 10^{10} \mathrm{~m}^{3}$ (Figure 5). It is apparent the average annual runoff for the Huai River was at a maximum in the 1950's followed by 2000's, 1980's, 1960's, 1970's and finally the 1990s. Comparing decadal values using an exponen 


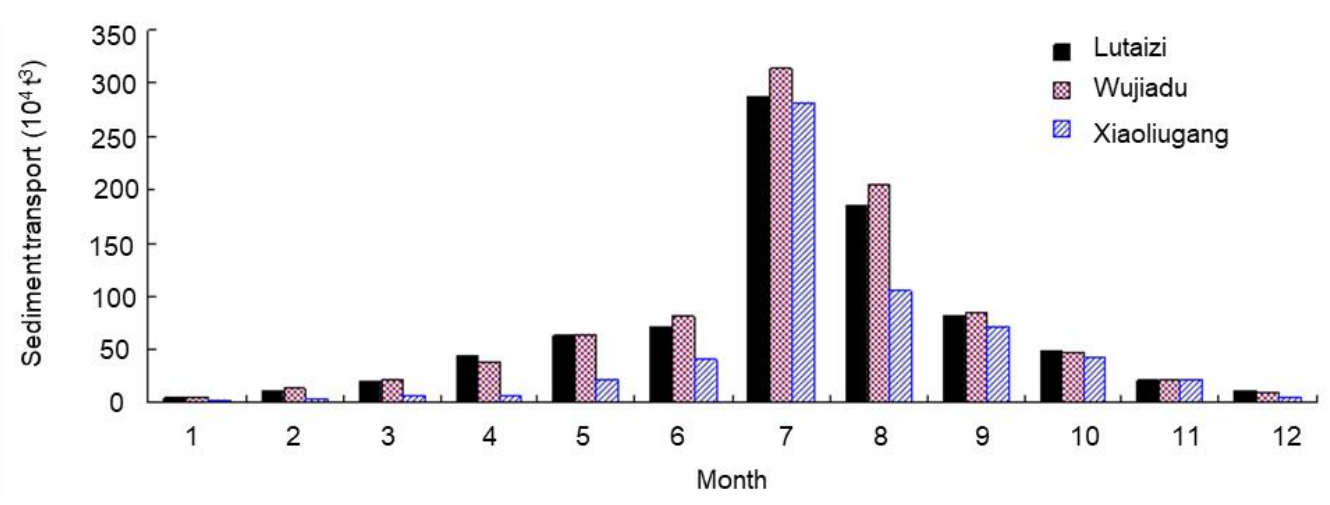

Figure 4. Average monthly sediment transport at the Lutaizi, Wujiadu and Xiaoliugang station.

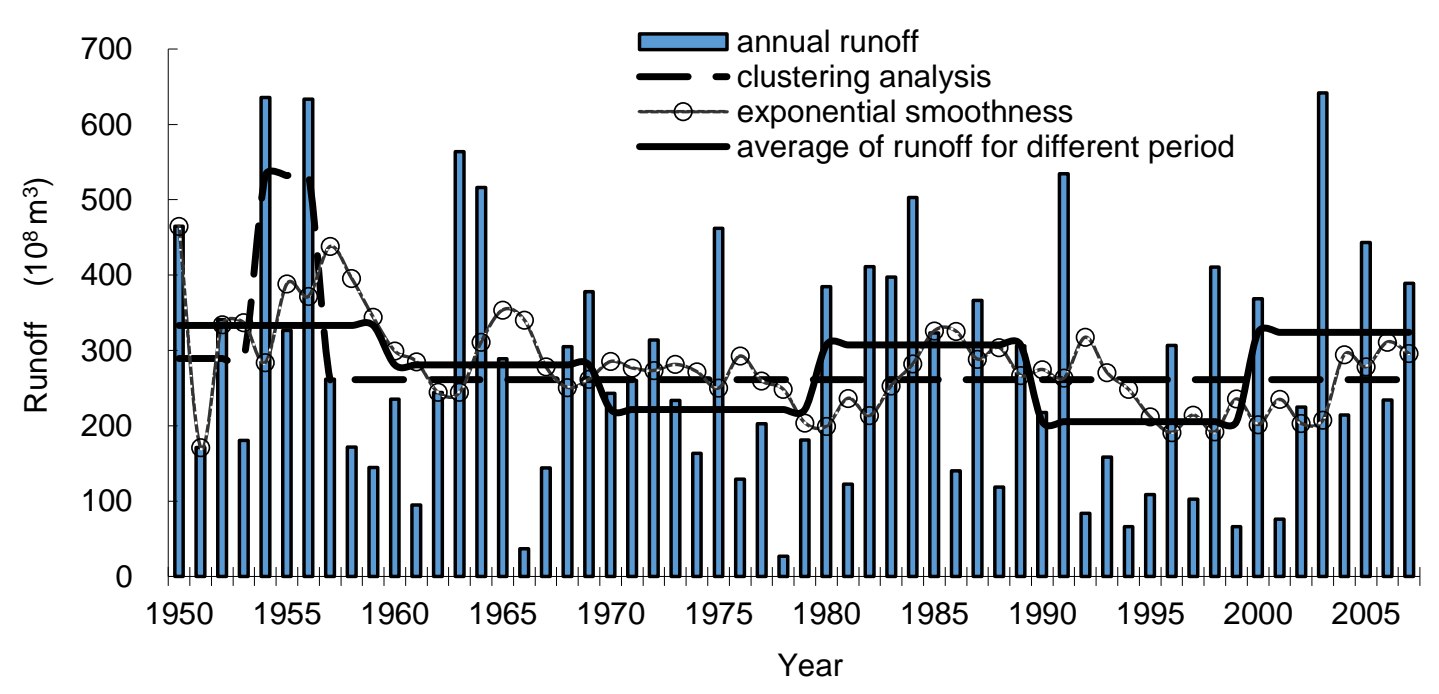

Figure 5. Trend analysis of runoff in the MRHR at the Wujiadu station.

Table 5. Monthly Mean Runoff with Standard Deviation

\begin{tabular}{|c|c|c|c|c|c|c|c|c|c|c|c|c|}
\hline Station & Jan & Feb & Mar & Apr & May & June & July & Aug & Sept & Oct & Nov & Dec \\
\hline Lutaizi & 3.34 & 4.88 & 7.67 & 11.46 & 15.95 & 20.21 & 39.98 & 35.06 & 22.49 & 16.55 & 10.87 & 6.05 \\
\hline Wujiadu & 4.60 & 7.11 & 9.93 & 13.37 & 18.80 & 24.45 & 43.78 & 46.04 & 31.31 & 22.69 & 15.23 & 7.71 \\
\hline Xiaoliuxiang & 5.51 & 6.21 & 8.53 & 10.21 & 13.95 & 18.14 & 50.97 & 47.72 & 36.32 & 28.53 & 20.12 & 8.86 \\
\hline
\end{tabular}

Table 6. Monthly Sediment Load with Standard Deviation

\begin{tabular}{|c|c|c|c|c|c|c|c|c|c|c|c|c|}
\hline Station & Jan & Feb & Mar & Apr & May & June & July & Aug & Sept & Oct & Nov & Dec \\
\hline Lutaizi & 5.34 & 17.86 & 25.53 & 124.16 & 92.51 & 112.36 & 384.88 & 309.20 & 119.34 & 92.38 & 32.53 & 20.63 \\
\hline Wujiadu & 9.22 & 33.15 & 34.32 & 105.01 & 101.44 & 123.66 & 267.23 & 253.59 & 101.39 & 68.40 & 35.08 & 20.96 \\
\hline Xiaoliuxiang & 4.23 & 6.35 & 9.24 & 17.86 & 33.31 & 62.84 & 292.45 & 148.10 & 94.16 & 69.97 & 32.37 & 9.24 \\
\hline
\end{tabular}

tial smoothness analysis indicates that the runoff of the Huai River fluctuates around the 58 years average value, albeit with only a minor variation. Clustering analysis shows that the runoff of the Huai River (at the Wujiadu station) has not changed much during this 58 years period. A clear step-increase (or step-decrease) in runoff has not been noticed.

Overall, a significant increase or decrease in runoff in the MRHR has not been noticed based on the assessments of runoff by using a statistical averaging method, the exponential smoothness method, or the clustering analysis.

\subsection{Trend Analysis of Sediment Transport}

Sediment transport for the Huai River and its branch rivers has decreased significantly over the past 20 years, as shown in Figure 6. Analysis of the data determined the statistical averages of sediment transport for different periods. Both an 


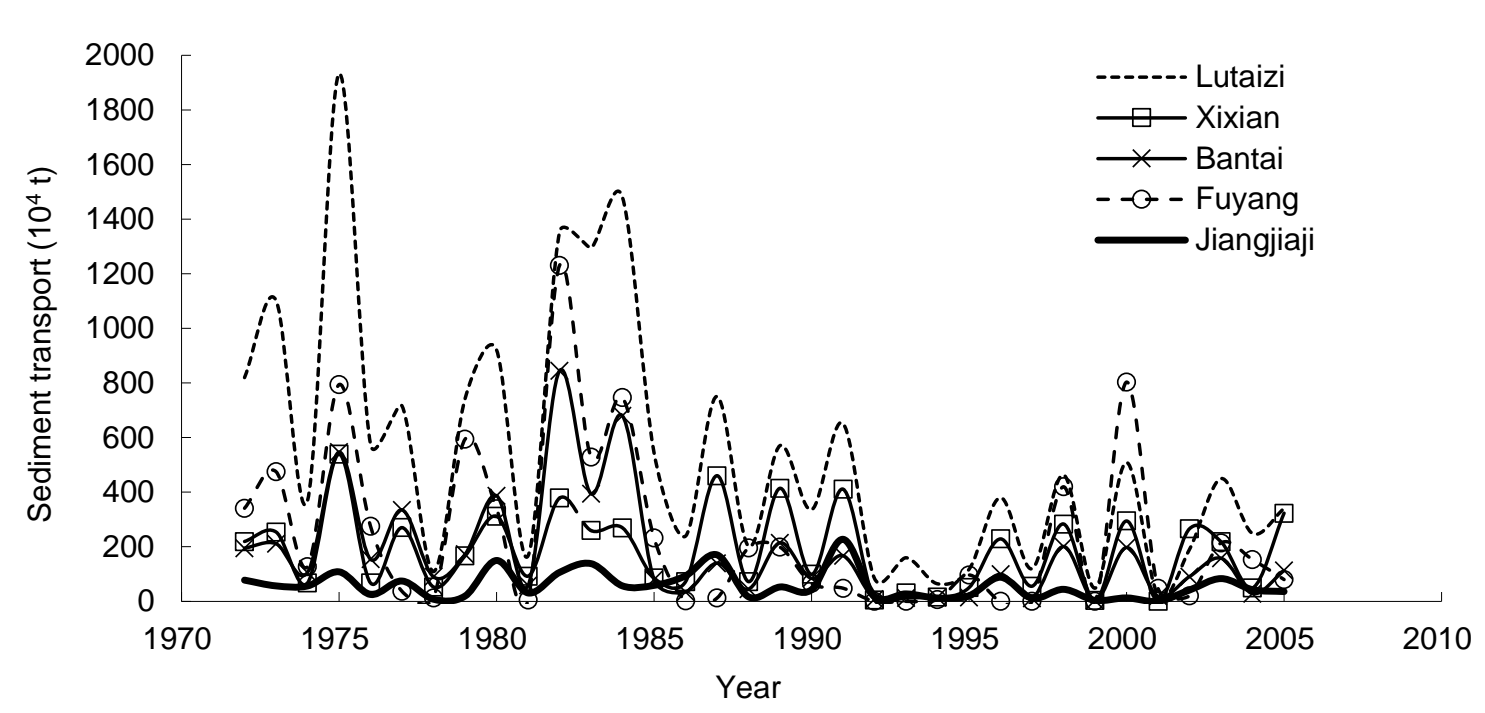

Figure 6. Changes in annual sediment transport at 3 gauging stations.

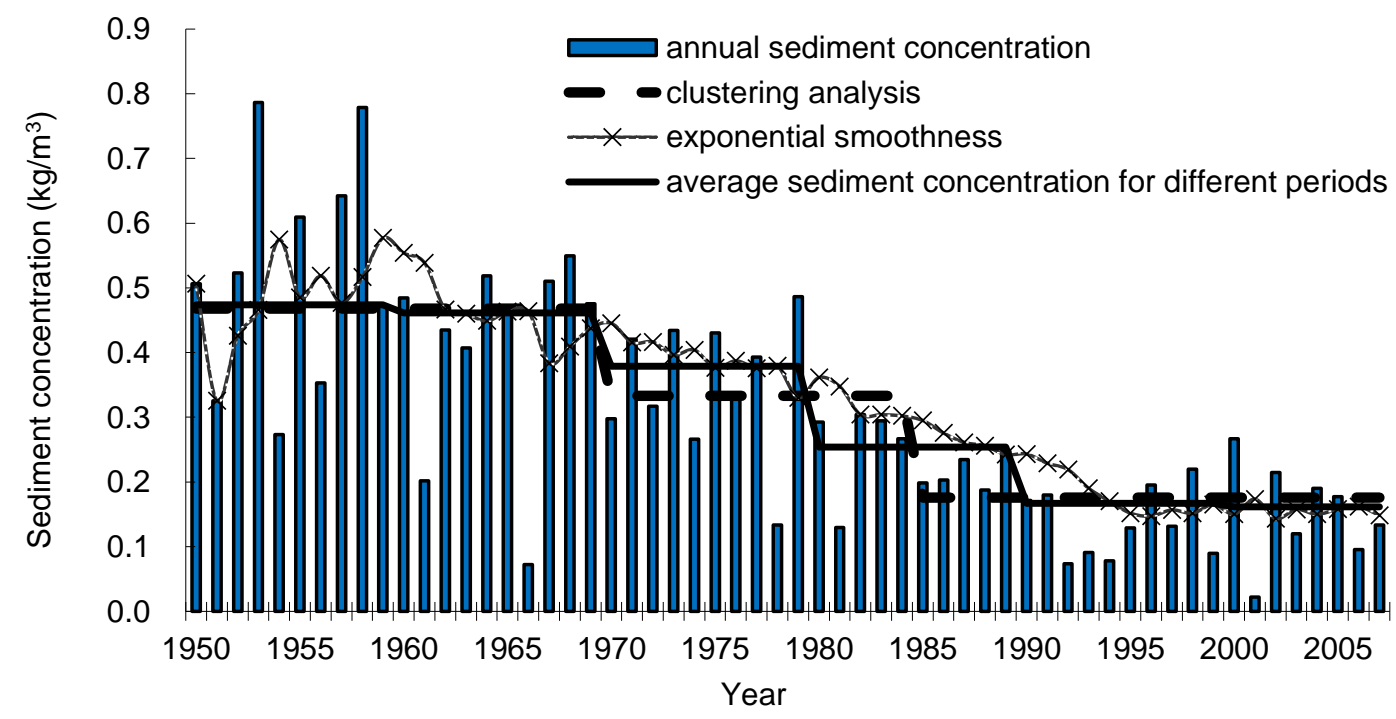

Figure 7. Trend analysis of sediment concentration in the MRHR at the Wujiadu station.

exponential smoothness analysis and clustering analysis have been carried out to study the features of sediment transport in the MRHR.

As shown in Figures 7 and 8, sediment concentration and transport in the Huai River at the Wujiadu station have gradually decreased since the 1950's until 2000 when the trendfor sediment transport started to increase due to high runoff. The results from the exponential smoothness analysis indicate that both sediment transport and sediment concentration for the Huai River have declined since the 1950s but have stabilized since the mid-1990s. In the last decade, the sediment concentration of the Huai River at the Wujiadu station has been approximately constant at $0.17 \mathrm{~kg} / \mathrm{m}^{3}$. The annual sediment transport of the Huai River at the Wujiadu station has also been approximately constant at $4.50 \times 10^{6}$ t. Clustering analysis also shows the sediment concentration and sediment transport at the
Wujiadu station have decreased. Thus, analysis of the data indicates recent sediment transport rates for the Huai River are only $30 \%$ of the rates obtained in the 1950 s.

Overall, a clear decrease in sediment transport and sediment concentration in the MRHR may be observed based on the data analysis for sediment transport and sediment concentration utilizing a statistical averaging method, an exponential smoothness method, and clustering analysis.

\subsection{Regression Model for Determining Sediment Trans- port}

Sediment in the sub-watershed of the MRHR mainly originates from the sub-watershed of the Upper Reach of the Huai River as observed at the Lutaizi station. To understand the decrease in sediment transport in the MRHR, a regression 


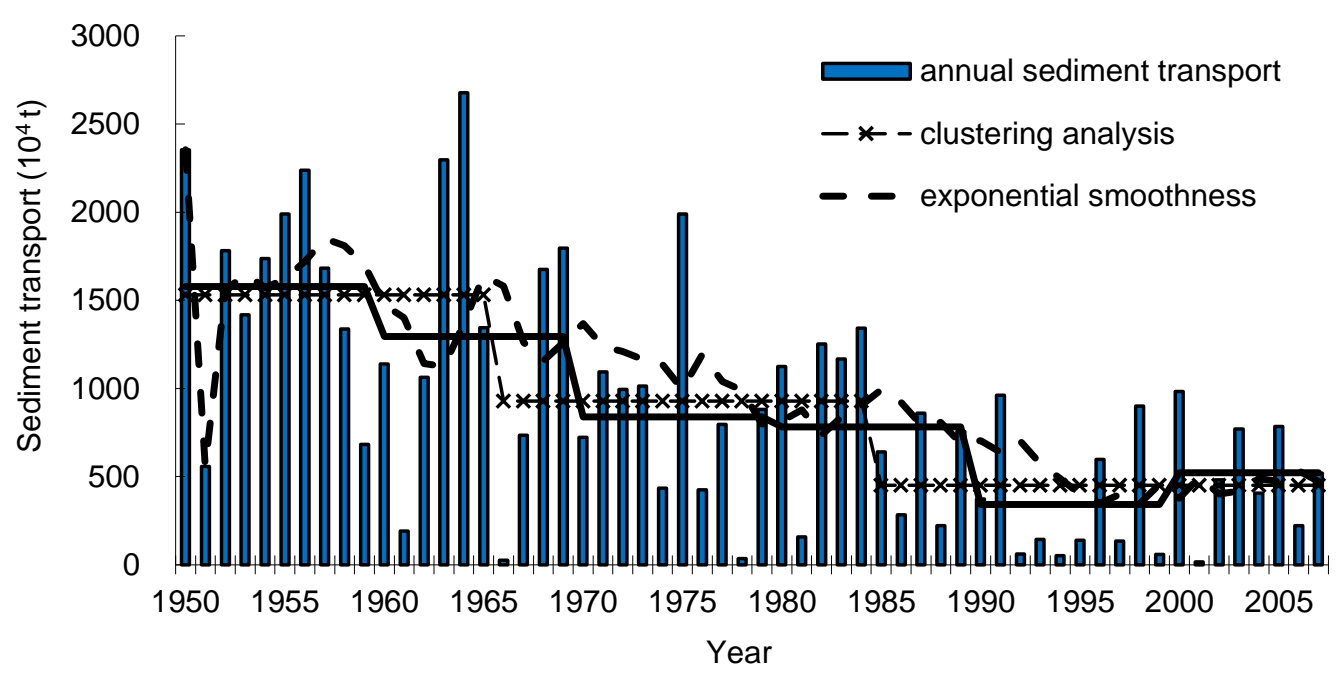

Figure 8. Trend analysis of sediment transport in the MRHR at the Wujiadu station.

model has been established for the Lutaizi station data to describe the impacts of the changes in sediment yield from some high sediment-yielding regions upstream of the Lutaizi station.

There are four important regions upstream of the Lutaizi station which have been observed to produce large quantities of sediment. Analysis of the sediment yield for these regions may be represented by sediment measurements at the following stations: the Xixian station on the Huai River, the Bantai station on the Hongruhe River, the Jiangjiaji station on the Shihe River, and the Fuyang station on the Shayinghe River. Based on data from 1950 to 2007, the following regression model was developed to determine sediment transport at the Lutaizi station:

$\mathrm{W}_{\mathrm{L}}^{\prime}=0.152 \mathrm{~W}_{\mathrm{X}}^{\prime}+0.436 \mathrm{~W}_{\mathrm{B}}^{\prime}+0.204 \mathrm{~W}_{\mathrm{J}}^{\prime}+0.307 \mathrm{~W}_{\mathrm{F}}^{\prime}$

where, $W_{L}^{\prime}, W_{X}^{\prime}, W_{B}^{\prime}, W_{J}^{\prime}$ and $W_{F}^{\prime}$ are standardized sediment transport at the Lutaizi station, Xixian station, Bantai station, Jianjiaji station and Fuyang station respectively.

The coefficients in Equation 4 represent the weighting factors of sediment contributed from these regions. Conceptually, the sum of the contribution factors of these 4 stations should equal $100 \%$. Hence, the contributions of the Xixian station, Bantai station, Jianjiaji station and Fuyang station are 13.8, $39.7,18.6$ and $27.9 \%$, respectively.

From the above analysis, sediment transport from the Hongruhe River would appear to play the most important role in sediment transport at the Lutaizi station on the Huai River, followed by the Shayinghe River and Shihe River. Sediment yield from the Upper River Reach of the Huai River plays the least significant role for sediment transport at the downstream Lutaizi station.

Sediment transport in the Hongruhe River and the Shayinghe River has decreased more than that in the Shihe River and the Upper Reach of the Huai River. Thus, one can conclude that the decrease in sediment transport in the MRHR at the Lutaizi station is mainly caused by the decrease in sediment transport in the branch rivers in the northern region of the Huai River, namely, the Hongruhe River and the Shayinghe River.

\subsection{Impacts of Changes in Sediment and Runoff on River- bed Deformation}

Both runoff and sediment transport play a significant role in the evolution of a riverbed while changes in runoff and sediment transport can lead to riverbed deformation.

Due to decreases since the 1950s in sediment transport for the Huai River, the deposition of sediment has decreased. This is observed through the analysis of riverbed deformation along the Middle Reach from the Lutaizi station to the Wujiadu station. Analysis of the data has shown that the average deposition capacity has also gradually decreased. Since 1980, this river reach has been scoured reaching a maximum in 2000. From 1980 to 2007 , the average annual scouring capacity has been calculated at $2.325 \times 106 \mathrm{t}$ as shown in Figure 9 ("+" represents deposition, and "-" represents scour).

Cross-sectional surveys carried out over time have shown that the main channel of the Huai River is normally scoured while the floodplain receives deposits of sediment. However, due to the significant decrease in sediment transport (or sediment concentration) of the Huai River since the 1950s, the scouring process in the main channel has been intensified and the deposition of sediment in the floodplain has decreased or reached an equilibrium condition. Along the Huai River from the Zhengyangguan station to the Bangbu-Gate station, the average annual scouring volume of sediment in main channel (AASVSMC) was $1.181 \times 10^{6} \mathrm{~m}^{3}$ from 1971 to 1983 while the average annual deposition volume of sediment in floodplain (AADVSF) was $7.95 \times 10^{5} \mathrm{~m}^{3}$. From 1983 to 1992 , AASVSMC was $2.216 \times 10^{6} \mathrm{~m}^{3}$, and AADVSF was $1.227 \times 10^{6} \mathrm{~m}^{3}$. From 1992 to 2001, AASVSMC was $5.192 \times 10^{6} \mathrm{~m}^{3}$ and AADVSF during this period was $1.60 \times 10^{5} \mathrm{~m}^{3}$. The scouring of the main channel of the Huai River has increased almost five-fold over this thirty year period while there appears to have been a similar 


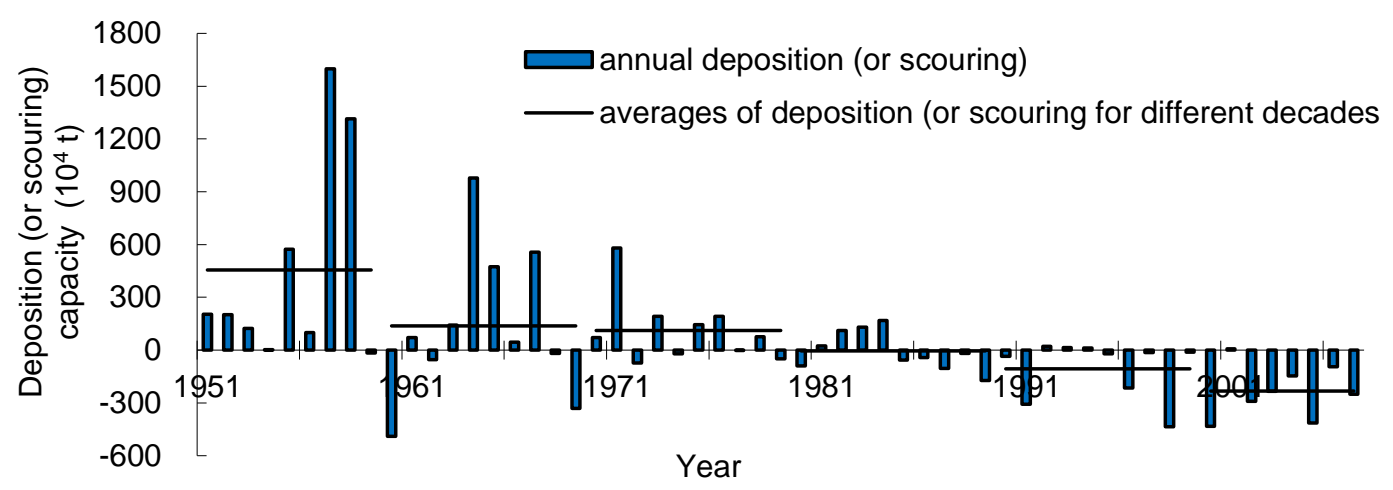

Figure 9. Deposition and scour capacity from the Lutaizi station to the Wujiadu station.

Table 7. Riverbed Deformation along the Estuary River Reach (1992 2000)

\begin{tabular}{llllllllll}
\hline $\begin{array}{l}\text { River } \\
\text { section }\end{array}$ & $\begin{array}{l}\text { Length } \\
(\mathrm{km})\end{array}$ & \multicolumn{2}{l}{ Deformation $\left(10^{4} \mathrm{~m}^{3}\right)$} & \multicolumn{3}{c}{ Average annual deformation $\left(10^{4} \mathrm{~m}^{3}\right)$} & \multicolumn{2}{c}{ Deformation speed $\left(\mathrm{cma}^{-1}\right)$} \\
\cline { 2 - 10 } & Main channel & Flood plain & Total & Main channel & Flood plain & Total & Main channel & Flood plain \\
\hline F-T & 25.24 & -389.4 & -9.7 & -399.1 & -43.3 & -1.1 & -44.4 & -3.72 & -0.20 \\
T-H & 14.96 & -328.5 & -44.7 & -373.2 & -36.5 & -5.0 & -41.5 & -2.74 & -1.18 \\
H-X & 20.35 & 398.5 & 635.0 & 1033.6 & 44.2 & 70.6 & 114.8 & 1.62 & 1.55 \\
X-L & 22.68 & 518.5 & 1395.3 & 1913.8 & 57.6 & 155.0 & 212.6 & 1.62 & 2.53 \\
\hline
\end{tabular}

* "Deformation speed" is defined as the ratio of the average amount of scour (or deposition) to the product of the channel width and channel length ** “+” represents deposition, and "-." represents scour

decline in sediment deposited on the flood plain.

The estuary river reach from the Huai River to the Hongzehu Lake may be used as an example to calculate the changes in riverbed deformation. The estuary river reach has been divided into following 4 sub-sections: the Fushan-Taiinggou section (F-T), the Taipinggou-Hongshantou section (T-H), the Hongshantou-Xuyi section (H-X), and the Xuyi-Laozishan section (X-L). The riverbed deformation from 1992 to 2001 has been calculated based on the changes observed for the cross sectional area.

As shown in Table 7, during the period from 1992 to 2000, upstream of the Hongshantou station (from the Fushan station to the Hongshatou station), the main channel of the estuary river reach was scoured with the average annual scouring capacity reaching $7.98 \times 10^{5} \mathrm{~m}^{3}$. However, the scouring process in the floodplain upstream of the Hongshantou station is much less, with an average annual scouring capacity of only $6.1 \times 10^{4}$ $\mathrm{m}^{3}$. In total, the scouring capacity along the estuary river reach upstream from the Hongshantou station was $8.59 \times 10^{5} \mathrm{~m}^{3}$. The average annual deposition capacity in the main channel along this section was $1.02 \times 10^{6} \mathrm{~m}^{3}$.

In the floodplain of the estuary river reach downstream of the Hongshantou station, severe deposition often occurs. The average annual deposition capacity in the floodplain along this section is $2.26 \times 10^{6} \mathrm{~m}^{3}$ whereas the deposition capacity along the estuary river reach downstream from the Hongshantou station is $3.28 \times 10^{6} \mathrm{~m}^{3}$ in total. Both the main channel and the flood plain are dominated by deposition processes downstream of the Hongshantou station. Furthermore, in the main channel of the estuary river reach, the total deposition of sediment from 1992 to 2000 was $1.99 \times 10^{6} \mathrm{~m}^{3}$ compared to a total deposition of sediment is $1.98 \times 10^{7} \mathrm{~m}^{3}$ in the flood plain. Overall, a total net deposition of sediment along this estuary river reach was $2.18 \times 10^{7} \mathrm{~m}^{3}$.

\section{Conclusions}

The changes in sediment transport, runoff, and riverbed deformation in the Middle Reach of the Huai River for the past 58 years have been analyzed. Results show that runoff yield from the Huai River watershed mainly occurs from the subwatershed of the Upper Reach of the Huai River. At the Wujiadu station, the difference in drainage area between south and north region of the Huai River is $43 \%$ while the difference in runoff yield is only $9 \%$. Sediment yield mainly comes from the northern headwater region with the upstream of the Huai River playing a secondary role. In contrast, the sediment yield from the various branch rivers in the southern region is relatively low. Results also indicate that while there has been little change in annual runoff in the MRHR, there has been a dramatic decrease in annual sediment transport due to the decrease in sediment yield from the Hongruhe and Shayinghe rivers. Even though there are no clear changes in flow discharge, sediment transport along this estuary river reach shows a significant decrease. This conclusion is supported by the trend analysis for both runoff and sediment transport, as well as regression analysis of the available data and cross-sectional analysis of the riverbed. The overall sediment yield in the Chinese rivers shows a similar trend. The present study can be used as a case study for the sediment prediction in other rivers around the world.

Acknowledgements: This research work has been supported by the following funding: "Technical and Scientific Innovation in Water 
Resources" of the Ministry of Water Resources of China (Grant No. XDS2007-1) and Major Science and Technology Program for Water Pollution Control and Treatment (Grant No. 2014ZX07204-006).

\section{References}

Dong, Y., Hui, X., Li, L. (2008). Preliminary Analysis on Characteristics and Changing Tendency of Annual Runoff and Sediment Load of Changjiang River Main Channels. J. Yangtze River Sci. Res. Inst. 25(2), 16-20. (In Chinese).

Huai River Conservancy Committee (HRCC). (2005). Huai River Plan Annals. Science Press, Beijing, China.

Liu, C., Sui, J., and Wang, Z. (2008). Runoff and sediment transport in the Yellow River. J. Environ. Inf., 12(2). 129-139. https://doi. org/10.3808/jei.200800131

Liu, X., He, D. (2011). A comprehensive assessment method of hydropower development impact on runoff and sediment change. $J$. Geogr. Sci., 66(7), 953-960. (In Chinese)

Ministry of Water Resources of China (MWR). (2001). River Sediment Bulletin of China 2000. China Water Power Press, Beijing, China.

Ministry of Water Resources of China (MWR). (2002). River Sediment Bulletin of China 2001. China Water Power Press, Beijing, China.

Ministry of Water Resources of China (MWR). (2003). River Sediment Bulletin of China 2002. China Water Power Press, Beijing, China.

Ministry of Water Resources of China (MWR). (2004). River Sediment Bulletin of China 2003. China Water Power Press, Beijing, China.

Ministry of Water Resources of China (MWR). (2005). River Sediment Bulletin of China 2004. China Water Power Press, Beijing, China.

Ministry of Water Resources of China (MWR). (2006). River Sediment Bulletin of China 2005. China Water Power Press, Beijing, China.

Shi, H., Shao, M. (2000). Soil and water loss from the loess plateau in China. J. Arid Environ., 45, 9-20. https://doi.org/10.1006/jare. 1999.0618
Sui, J., He, Y., and Karney, B. (2008). Flow and high sediment yielded from the Huangfuchuan watershed. Int. J. Environ. Sci. Technol., 5(2), 149-160. https://doi.org/10.1007/BF03326008

Sui, J., He, Y., and Liu, C. (2009). Changes in sediment transport in the Kuye River in the Loess Plateau in China. Int. J. Sediment Res., 24(3), 201-213. https://doi.org/10.1016/S1001-6279(09)60027-5

Walling, D.E. (2005). Recent changes in the suspended sediment transport modulus of the world's rivers: the impact of environmental Change. The 3rd ISI steering Committee Meeting, 28-30, 2005 Vienna, Austria.

Walling, D.E. (2006). Human impact on land-ocean sediment transfer by the world's rivers. Geomorphology, 79(3), 192-216. https://doi. org/10.1016/j.geomorph.2006.06.019

Walling, D.E. and Fang, D. (2003). Recent trends in the suspended sediment transport modulus of the world rivers. Global Planet. Change, 39, 111-126. https://doi.org/10.1016/S0921-8181(03)00020-1

Wang, Z.Y. and Wu, Y.S. (2001). Sediment-removing capacity and river motion dynamics, Int. J. Sediment Res., 16(2), 105-115.

Xu, J.X. (2003). Sedimentation rates in the lower Yellow River over the past 2300 years as influenced by human activities and climate change. Hydrol. Process., 17(16), 3359-3371. https://doi.org/10.10 02/hyp.1392

Yang Z., Jiang C., and Zhang. Y., Qi J. (2011). The sediment and runoff variation from the Sanhukou to Zhaojunfen in the Yellow River. China Rural Water Hydro., 9, 21-25. (In Chinese).

Yu, B., Wu, P., Sui, j., Yang, X., and Ni, J. (2014). Fluvial geomorphology of the Middle Reach of the Huaihe River. Int. J. Sediment Res., 29(1), 24-33. https://doi.org/10.1016/S1001-6279 (14) 60019-6

Zhang C., Zhang Y., and Gao J. (1996). Characteristics of Runoff, Sediment and Fluvial Processes in the Lower Weihe River in Recent Years. Sediment Res, 3, 17-25. (In Chinese). 